\title{
What comes after the lockdown? Clustering of ANCA-associated vasculitis: single-centre observation of a spatiotemporal pattern
}

Antineutrophil cytoplasm antibodies (ANCA)-associated vasculitides (AAV) are characterised by a heterogeneous clinical phenotype. ${ }^{1}$ We report a cluster of 15 patients diagnosed with AAV either de novo $(n=11)$ or with relapsing disease $(n=4)$ during COVID-19 pandemic between February and August 2020. During this period, we observed two major phenomena: (1) an incidenceshift with a 'COVID-gap' of no diagnosed AAV cases during the lockdown period (March and April), followed by a 'postlockdown cluster' of 14 active patients (8 myeloperoxidase-ANCA, 6 proteinase 3-ANCA vasculitis) in the subsequent 4 months and (2) an increased incidence rate (figure 1 and online supplemental figure S3). Mean creatinine at baseline was $3.66 \mathrm{mg} / \mathrm{dL}$. Inflammatory markers were significantly elevated in most patients, with a mean C reactive protein value of $9.93 \mathrm{mg} / \mathrm{dL}$ and an erythrocyte sedimentation rate of $83 \mathrm{~mm}$ per first hour. Despite detrimental effects on humoral immunity, ${ }^{2}$ most patients received two doses of rituximab and methylprednisolone. No severe treatment complications occurred. SARS-CoV-2 PCR and serology were negative in tested patients. Further clinical and radiological characteristics are provided in online supplemental tables S1 and S2).

Comparable observations were recently reported from Italy, where a cluster of nine patients with AAV was detected in the second trimester of 2020. Kidney replacement therapy was necessary in seven of nine patients and one patient died. ${ }^{3}$ In contrast to these findings, disease courses in our cohort were comparably mild with a mean creatinine of $2.48 \mathrm{mg} / \mathrm{dL}$ at last follow-up and only one patient requiring intermittent kidney replacement therapy after spontaneous kidney bleeding from disseminated pseudoaneurysms.

The clustering of AAV in our centre may be attributable to a delayed presentation to our clinic. Containment measures may cause deferral of initial presentation after onset of symptoms by several means: (1) patients may be frightened of demanding healthcare services and (2) infrastructural cutbacks, such as restricted availability of public transports and an overall reduced access to healthcare institutions, further exacerbate this situation. Such delayed diagnoses may have significant impacts. For example, fast-track services facilitating immediate treatment have been 


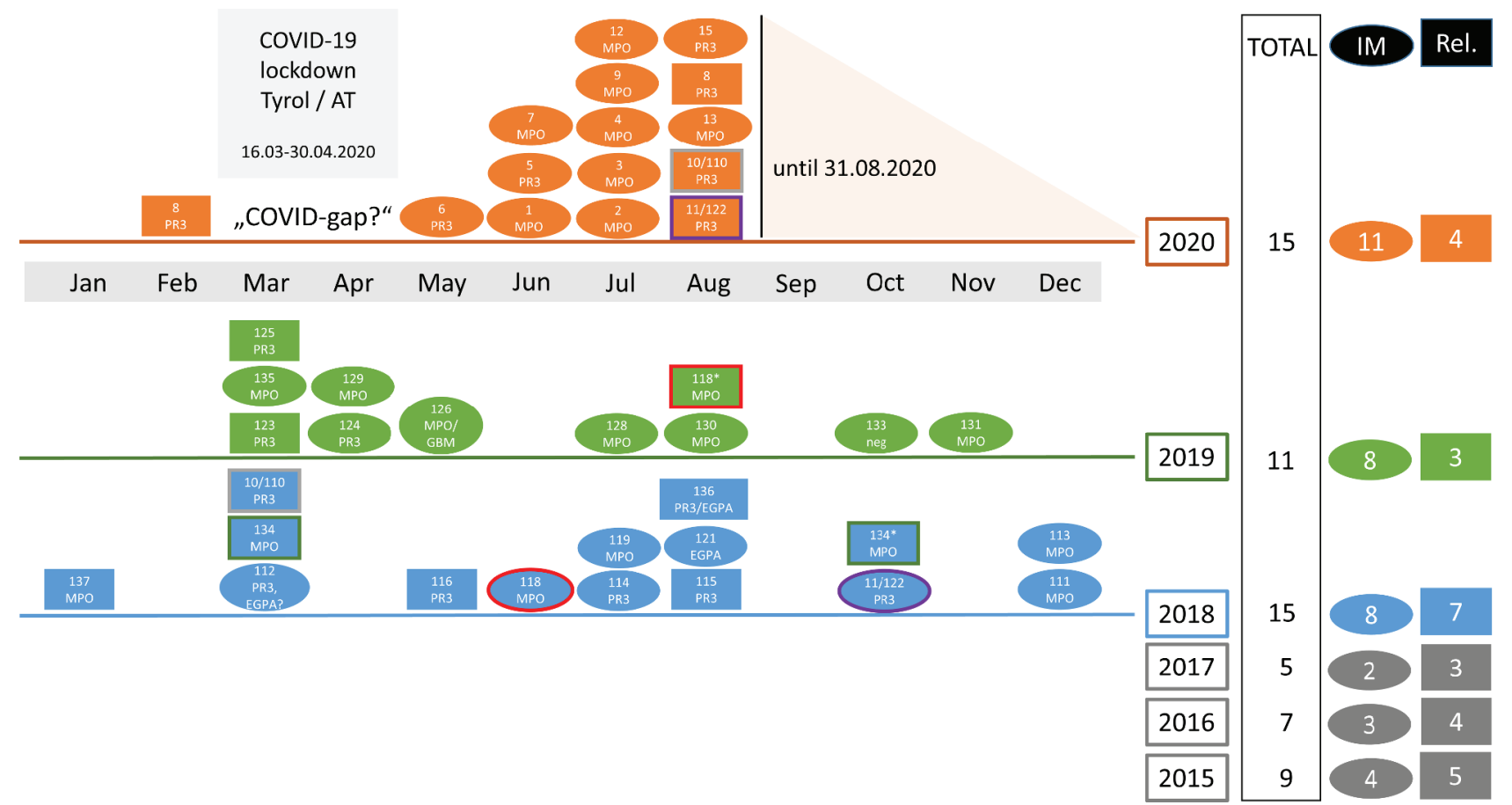

Figure 1 Timeline of incident ANCA-associates vasculitis cases in 2018, 2019 and 2020. Incident cases are posed on a timeline at the time of diagnosis of either initial manifestation (oval) or disease relapse (box). Duplicates are marked as such by a coloured frame. Numbers in boxes/ovals match with respective identity (ID) in online supplemental table S1. ANCA, antineutrophil cytoplasmic antibody; AT, Austria; IM, initial manifestation; MPO, myeloperoxidase; PR3, proteinase 3; Rel, relapse.

established for patients with giant cell arteritis who are at risk of blindness. A reduction of $75 \%$ in the request for such fast-track assessment, compared with the same time frame in 2019, was recently reported from a centre in Italy. Two cases of irreversible bilateral visual loss were attributed to a delayed diagnosis and deemed preventable. ${ }^{4}$

Our findings underline previous observations that the COVID-19 pandemic has significant impact on patients with diseases other than COVID-19. ${ }^{5}$ Although definite conclusions on clinical outcomes cannot be yet drawn, our observations indicate no detrimental effects of COVID-19 on clinical outcomes of non-infected patients with AAV. Nonetheless, prompt diagnoses and referrals currently affected by the ongoing global pandemic are crucial in the disease management. Compared with the previous years, we observed an over twofold increased incidence rate of AAV diagnoses (1.9 cases per month in 2020 vs 0.8 cases from 2015 to 2019) and almost threefold increased incidence rate of de novo AAV manifestations (1.2 de novo cases per month in 2020 vs 0.4 de novo cases from 2015 to 2019). This may not only be attributed to deferral of symptoms and delayed diagnoses, as patients showed significant overall improvement following initiation of immunosuppression. Though geographical clustering of AAV may be attributed to certain environmental factors, ${ }^{6}$ the impact of such factors on disease incidence remains elusive thus far. Finally, whether COVID-19 could be a trigger of regional clustering either directly (infection) or indirectly (effects of containment measures, eg, decreases in carbon dioxide emissions due to reduced air/ground travel or psychosocial consequences of a lockdown) is speculative and should be subjected to further investigation.

Philipp Gauckler $\odot$, ${ }^{1}$ Erica L Bettac, ${ }^{2}$ Manfred Nairz, ${ }^{3}$ Christina Duftner, ${ }^{3}$ Anna K Luger, ${ }^{4}$ Markus Stein, ${ }^{5}$ David Wanner, ${ }^{5}$ Barbara C Böckle, ${ }^{6}$ Martin Tiefenthaler, ${ }^{1}$ Peter Schratzberger, ${ }^{1}$ Hannes Neuwirt, ${ }^{1}$ Lukas Harasser, ${ }^{1}$ Gert Mayer, ${ }^{1}$ Andreas Kronbichler $\odot^{1}$
'Department of Internal Medicine IV Nephrology and Hypertension, Innsbruck Medical University, Innsbruck, Austria

${ }^{2}$ Department of Psychology, Washington State University Vancouver, Vancouver, Washington, USA

${ }^{3}$ Department of Internal Medicine II, Infectious Diseases, Immunology, Rheumatology, Pneumology, Medical University Innsbruck, Innsbruck, Austria

${ }^{4}$ Department of Radiology, Medical University Innsbruck, Innsbruck, Austria ${ }^{5}$ Department of Pneumology, Public Hochzirl-Natters Hospital, Natters, Austria ${ }^{6}$ Department of Dermatology and Venereology, Medical University Innsbruck, Innsbruck, Austria

Correspondence to Dr Andreas Kronbichler, Department of Internal Medicine IV (Nephrology and Hypertension), Innsbruck Medical University, Innsbruck 6020, Austria; andreas.kronbichler@i-med.ac.at

\section{Handling editor Josef S Smolen}

Twitter Andreas Kronbichler @akronbichler

Contributors AK and PG conceived the letter. PG wrote the first draft of the manuscript and designed the figures. ELB did statistical analysis. All other coauthors critically revised the manuscript, carried out major modifications and approved the final version.

Funding The authors have not declared a specific grant for this research from any funding agency in the public, commercial or not-for-profit sectors.

Competing interests $C D$ reports personal fees and non-financial support from Abbvie, personal fees from AOP Orphan, personal fees from Actelion, personal fees from AstroPharma, personal fees from Celgene, personal fees from Böhringer Ingelheim, personal fees and non-financial support from BMS, personal fees from Lilly, personal fees from MSD, personal fees from Novartis, personal fees and nonfinancial support from Pfizer, personal fees and non-financial support from Roche, personal fees from Sandoz, personal fees from UCB, outside the submitted work; $B C B$ reports personal fees from Lilly, non-financial support from Lilly, non-financial support from Sanofi Aventis, personal fees from Sobi Austria, outside the submitted work.

Patient consent for publication Not required.

Provenance and peer review Not commissioned; externally peer reviewed.

Supplemental material This content has been supplied by the author(s). It has not been vetted by BMJ Publishing Group Limited (BMJ) and may not have been peer-reviewed. Any opinions or recommendations discussed are solely those 
of the author(s) and are not endorsed by BMJ. BMJ disclaims all liability and responsibility arising from any reliance placed on the content. Where the content includes any translated material, BMJ does not warrant the accuracy and reliability of the translations (including but not limited to local regulations, clinical guidelines, terminology, drug names and drug dosages), and is not responsible for any error and/or omissions arising from translation and adaptation or otherwise.

\section{(2) \\ OPEN ACCESS}

Open access This is an open access article distributed in accordance with the Creative Commons Attribution Non Commercial (CC BY-NC 4.0) license, which permits others to distribute, remix, adapt, build upon this work non-commercially, and license their derivative works on different terms, provided the original work is properly cited, appropriate credit is given, any changes made indicated, and the use is non-commercial. See: http://creativecommons.org/licenses/by-nc/4.0/.

C Author(s) (or their employer(s)) 2021. Re-use permitted under CC BY-NC. No commercial re-use. See rights and permissions. Published by BMJ.

- Additional material is published online only. To view, please visit the journal online (http://dx.doi.org/10.1136/annrheumdis-2020-219212).

\section{D) Check for updates}

To cite Gauckler P, Bettac EL, Nairz M, et al. Ann Rheum Dis 2021;80:669-671.

Received 30 September 2020

Revised 4 November 2020

Accepted 21 November 2020

Published Online First 1 December 2020

Ann Rheum Dis 2021;80:669-671. doi:10.1136/annrheumdis-2020-219212

\section{ORCID iDs}

Philipp Gauckler http://orcid.org/0000-0002-5964-0307

Andreas Kronbichler http://orcid.org/0000-0002-2945-2946

\section{REFERENCES}

1 Kitching AR, Anders H-J, Basu N, et al. ANCA-Associated vasculitis. Nat Rev Dis Primers 2020;6:71.

2 Kronbichler A, Gauckler P, Windpessl M, et al. COVID-19: implications for immunosuppression in kidney disease and transplantation. Nat Rev Nephrol 2020;16:365-7.

3 Giollo A, Bixio R, Gatti D, et al. Challenge of diagnosing ANCA-associated vasculitis during COVID-19 pandemic: a missed 'window of opportunity'. Ann Rheum Dis 2020. doi:10.1136/ annrheumdis-2020-218830. [Epub ahead of print: 19 Aug 2020].

4 Monti S, Delvino P, Bellis E, et al. Impact of delayed diagnoses at the time of COVID-19: increased rate of preventable bilateral blindness in giant cell arteritis. Ann Rheum Dis 2020;79:1658-9.

5 Metzler B, Siostrzonek P, Binder RK, et al. Decline of acute coronary syndrome admissions in Austria since the outbreak of COVID-19: the pandemic response causes cardiac collateral damage. Eur Heart J 2020;41:1852-3.

6 Lee JHM, Attygalle T, Gaffney K, et al. Demographics and environmental factors in a Wegener's granulomatosis cluster. Ann Rheum Dis 2007;66:278-9. 